\begin{tabular}{ll}
\hline \hline MINING AND METALLURGY INSTITUTE BOR & ISSN: 2334-8836 \\
& UDK: 622 \\
\hline \hline
\end{tabular}

UDK: $622.271: 504.06(045)=20$

DOI:10.5937/MMEB1402001M

\author{
Miroslava Maksimović, Milenko Jovanović, Goran Pačkovski", \\ Vladan Marinkovic ${ }^{*}$
}

\title{
PRELIMINARY GEOLOGICAL EXPLORATION WORKS IN ORDER TO THE ENVIRONMENTAL MANAGEMENT IN THE AREA OF INACTIVE ECOLOGICAL MINING FIELD ${ }^{* *}$
}

\begin{abstract}
Bor is otherwise a typical mining town, founded by the mine. Continued economic activity in the dominant area of extractive industry, related to the copper ore mining and processing, then for metallurgy and complementary industrial activities, what is of great importance for the town and the municipality. The northern part of the Timok magmatic complex and the Bor metallogenic zone, or the Bor mining region, covers the area in which the most significant ore fields are Bor, Veliki Krivelj Cerovo, Majdanpek, Blagojev Kamen and others. The largest technogenic formations were separated in the immediate vicinity of the Bor and Krivelj mine, and they are presented by formations originated by exploitation of mineral copper deposits (overburden) and mineral processing (flotation tailing dumps) in the immediate vicinity of Bor. Designed exploration works in the area of environmental inactive mining field were aimed to prepare the conditions for environment management, remediation of tailing dumps and landfills for disposal of mining waste in the Bor mining areas as well as the rehabilitation of ecological problems in the ore region of Bor. Exploration works included the study of the field: for disposal the tailings from Veliki Krivelj area of the Old Bor Tailing Dump (East), Saraka overburden dump, south-eastern overburden dump and RTH.

Keywords: technogenic formations, inactive ecological exploitation field, ore mining, tailing dump,
\end{abstract} landfills for disposal of mining waste

\section{INTRODUCTION}

Morphology of the terrain in the area of wider surrounding of exploration area affects the methods and conditions of exploration and exploitation, and the conditions of transport the ore and concentrate, and disposal of technogenic formations. Similarly is with the hydrological conditions, especially the waterways.

Intensive volcanic activity (the late Mesozoic and during Cenozoic) had a significant impact on the terrain relief in wider area of Bor, followed by strong tectonic movements. Tectonic movements, which are reflected in the breaking out, gravitational and reverse movements of blocks, as well as folding of the field, resulted in the primary modelling of geomorphologic forms, which were further modified by the influence of exogenous factors.

\footnotetext{
* Mining and Metallurgy Institute Bor

** This work is the result of the Project TR37001 "The Impact of Mining Waste from RTB Bor on the Pollution of Surrounding Water Systems with the Proposal of Measures and Procedures for Reduction Harmful Effects on the Environment", funded by the Ministry of Education, Science and Technological Development of the Republic of Serbia
} 
However, the formation of current look of relief was influenced by the economic activity in the mineral-raw material complex (Figures 1, 2, 3). The processes of exploitation, preparation, and processing of ore in Bor and its surroundings, caused the changes of relief and formation of some inverse morphological forms, such as the open pits and landfills (rock overburden, mining waste, flotation tailings, smelter slags, calcined pyrite).
Exploitation of the Bor deposit, since the beginning of the last century, has included 26 ore bodies, largely at the same time by the and underground mining (Figure 1). Thereby was obtained total of 146 270000 tons of ore from which copper was extracted 2,437 million tons of metal copper, $139140 \mathrm{~kg}$ of gold and 415000 $\mathrm{kg}$ silver. It was also excavated 436,2 million tons of waste mass (overburden and associated rocks).

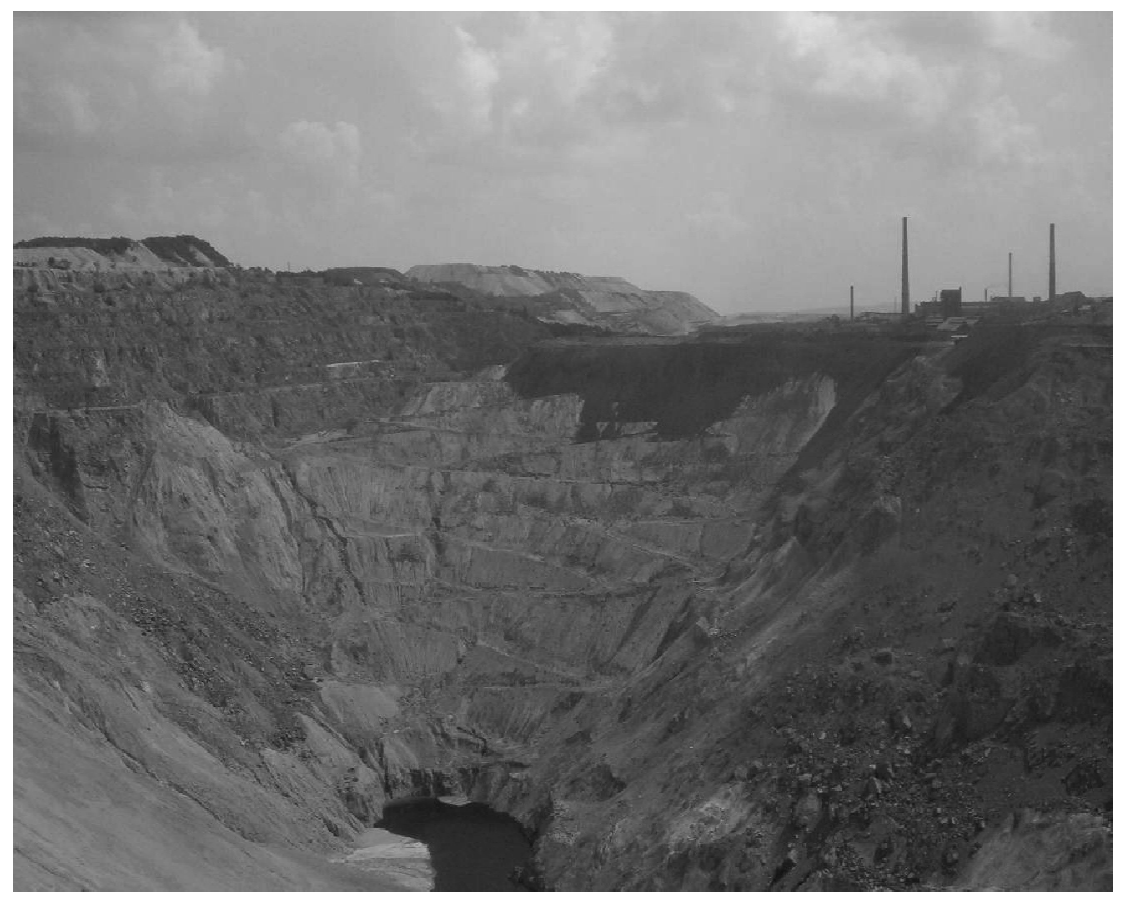

Figure 1 The Old Bor Open Pit (August 2005)

The exploitation of copper deposit at the old open pit in Bor (Figure 1), and later by the underground mining as well as enrichment of ore and production of concentrate in the Bor Flotation Plant, have caused the changes paleorelief in terms of degradation the natural terrain, creating the elevations of accumulated material of flotation tailings. Metallurgical treatment of concentrates resulted in the formation of slag landfill. The largest amount of slag is disposed at the site between the open pit and ore body "H" and former Pralište of the workshops at the old open pit, and this location is known as the "Slag Depot - 1" [I].

The first works on stripping the open pit Veliki Krivelj began in 1979. Excavation of copper ore began in 1982, and total were excavated and processed about 198 million tons of ore with about 689.000 tons of copper metal and approximately 179 million tons of tailings (Figure 2). 


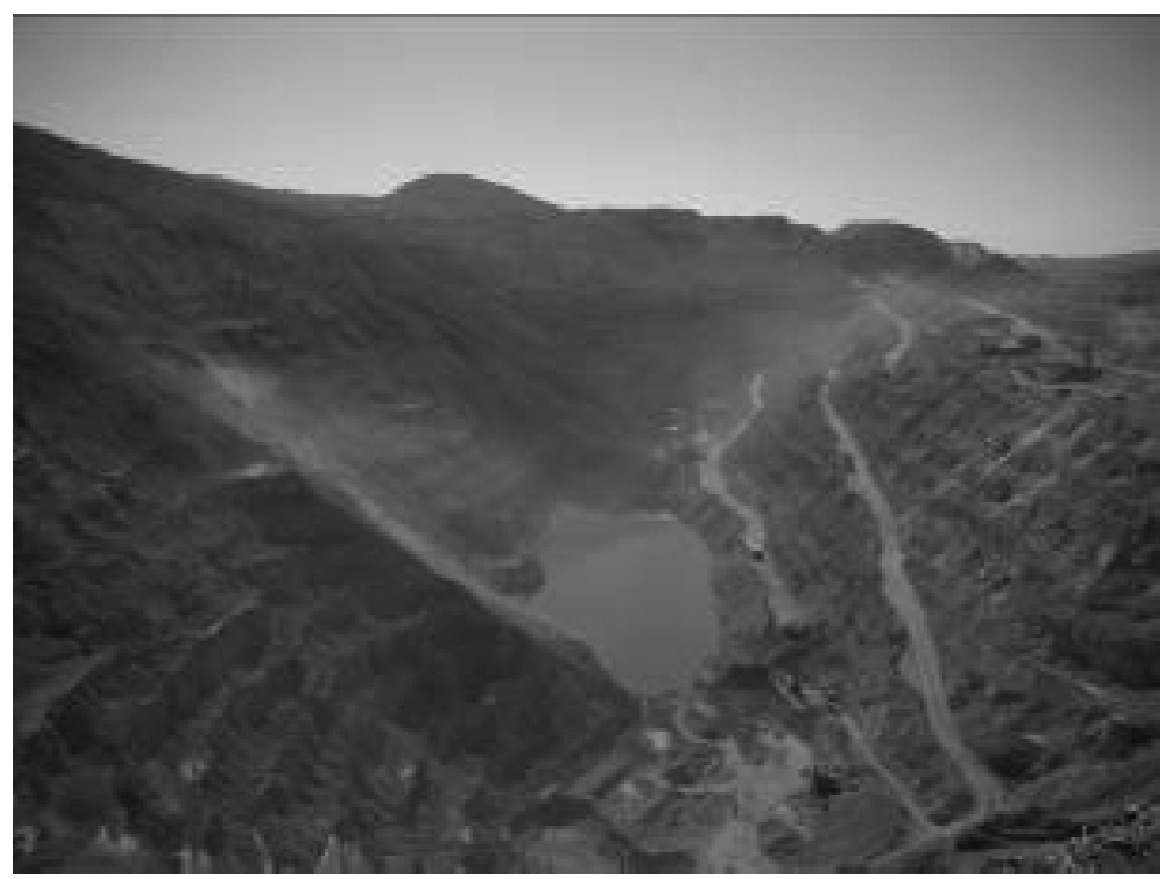

Figure 2 View of the open pit Veliki Krivelj (2012)

Processing of copper ore from the open pit Veliki Krivelj is performed in the Flotation Plant Veliki Krivelj. The designed capacity of the Veliki Krivelj Flotation Plant is 8000000 tons of dry ore per year, or expressed by hour capacity of $342.5 \mathrm{t} / \mathrm{h}$ of dry ore per section.

The tailing dump Veliki Krivelj is, due to different time of construction and use, divided into two parts - the fields. Field 1 is located between Dams 1 and 2, and Field 2 is the area between the Dams 2 and 3. The use of Field 1 began in December 1982 and it was temporarily suspended in September 1990. Field 2 has been used since September 1990 and today is active.

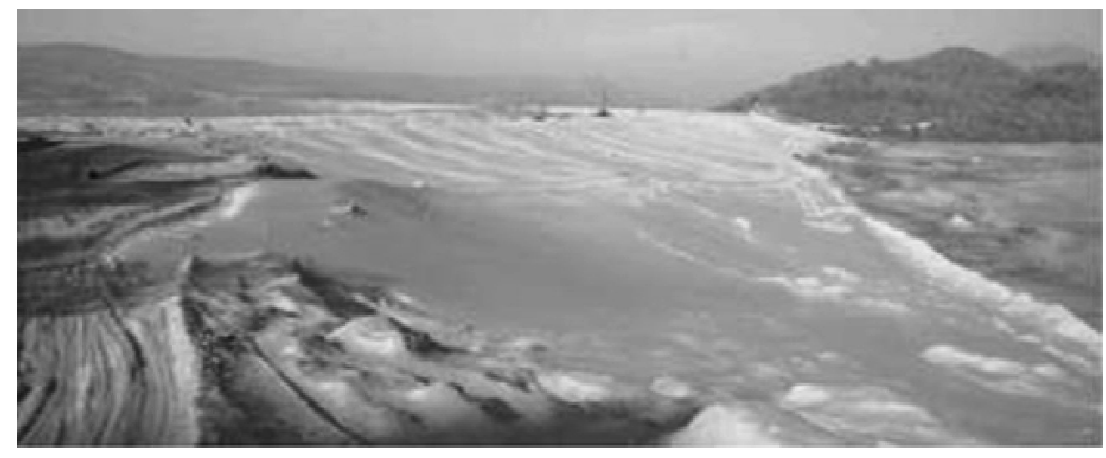

Figure 3 Dam 2 of the Veliki Krivelj flotation tailing dump (2011) 


\section{PRELIMINARY EXPLORATION WORKS}

Preliminary exploration works are focused on testing the field for exploration, rehabilitation, remediation and reclamation: the Old Bor flotation tailing dump: landfill of tailings of the Veliki Krivelj dump, stability of the Dams 2 and 3 on Field 2, Saraka overburden dump, south-eastern overburden dump and RTH (Figure 4).

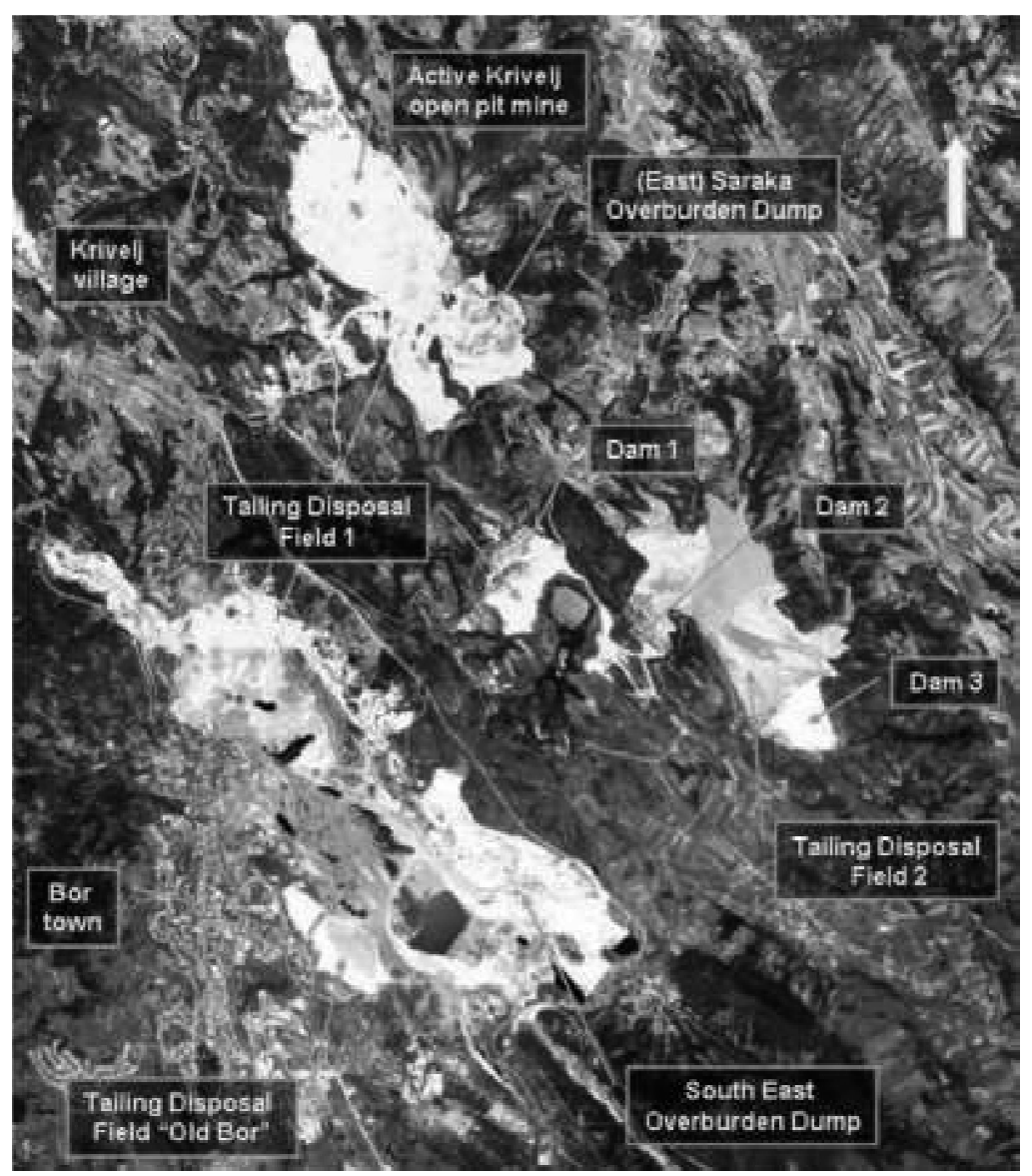

Figure 4 Location plan of landfills and tailing dumps (2011)

The basic aims of exploration are:

1. from landfills and remediation (mainly mining waste material),

2. stability of the dams,

3. water control (storm water, water refilling, water leakage, uncontro- lled water leakage and sludge spilling),

4. closure and remediation of tailing dump in Bor, and partially re-planting of vegetation, and

5. monitoring and maintenance after construction. 
Special attention is given to the rehabilitation/re-routing the bypass of the river (collector) that is now below the tailing dump Veliki Krivelj.

The objectives of this particular task are:

1. investigation of the location,

2. design works,

3. development the impacts on the environment,

4. development the plan of environment management,

5. preparation the monitoring plan for rehabilitation and remediation.

Specific objectives:

1. Implementation of environmental studies of the field and geological and hydrogeological explorations to obtain data for future remediation/reclamation of the land;

2. Elaborate of inputs for full assessment the impact on the environment, the projects of environmental management and remediation projects of the locations.

Preliminary geological works include: exploration drilling to take samples for determination the chemical composition, leaching tests, mining waste and flotation tailings, determination the geological structure of paleorelief, installation of piezometers to monitor the quality and level of water, taking samples for acid generation tests and neutralization of engineering-geological explorations to determine the stability of dams (Maksimović M., 2011., 2012.).

In addition to geological explorations in the field, further explorations include some specific activities that are relevant to the rehabilitation and reclamation of the subject areas. These activities include: sampling of surface soil (potential) surfaces of the mine landfills and tailing dumps for testing the acid generalization and neutralization; tests of biological reclamation, including smallscale tests on the ground with plants; tests for biological reclamation suitable for assessment the plant growth conditions.
In general, the field research began with detailed penetration testing the ground of landfill of the mine waste and flotation tailings to assess the composition of the soil. Further explorations were continued by exploration drilling. The final position and depth of the piezometers were selected on the basis of penetration tests and core drilling and soil stratigraphy as determined during drilling.

Static network test probes, up to 5 feet deep, were performed before the testing network of shear and core drilling.

In order to verify the effectiveness of the proposed stability and measures to reduce leakage, a comprehensive monitoring plan that was developed and implemented, consists of instrumental monitoring and visual inspection.

\section{THE RESULTS OF CONDUCTED EXPLORATIONS AND TESTING}

Flotation tailing dumps and dams on tailing dumps, over the years were built from materials of cyclone tailings, consisting of fine grained (silty) to coarse grained sand (loose material).

Stability of the dam is secured until the groundwater level within the body of the dam can be maintained below maximum safe level, especially taking into account the expected seismic conditions. The current efforts to control the groundwater levels are insufficient as evidenced by high amount of (contaminated) leakage that now appears through the dam (Maksimović M., 2011, 2012.).

For successful implementation the remediation Project, it is necessary that the current flow of leachate to be stopped.

Before taking actions, it is recommended to conduct firstly a rapid assessment of the risk to determine the potential impacts of possible collapse of dams and to evaluate the effectiveness and scope of the proposed remediation measures and remediation and reclamation of inactive landfills. 
On the basis of realized explorations and testing, it was determined that the following measures have to be taken:

- Plan of vegetation should be adopted for the slopes of dams to prevent the future surface erosions the filling of dams;

- Redesign of the drainage system to prevent leakage and improve the stability of the systematic and effective lowering the groundwater levels within dams and in their immediate vicinity.

\section{CONCLUSION}

The exploration area, located in the area of environmental inactive mining field, is the space, in which the presence of hazardous and harmful substances is confirmed caused by human activity in concentrations that may cause a significant risk to the human health and environment.

The area of environmental inactive mining field was explored by the exploration drill holes from the field surface. The realized geological explorations provided the preliminary data on geological structure, physico-mechanical and hydrological characteristics of the areas of ecological inactive mining field.

Based on the results of realized explorations and testing, the further measures were proposed for rehabilitation of the subject area, and reduction of pollution. Further explorations will get the results to take measures to stop further pollution and environmental degradation to a level that is safe for the future use of the site including landscaping, rehabilitation and reclamation.

\section{REFERENCES}

[1] Maksimović M., Nikolić K., et al., Elaborate on Reserves of the Copper Deposit Bor (Ore Bodies "Brezanik", "Tilva Roš" and "P2A"), state on 31/12/2004-textual part, Fund of Technical Documentation, Geology Department, MMI, Bor; 2005, p.144.

[2] Maksimović M.: Project of Detailed Geological Explorations of Copper and Other Useful Components in the Area of the Old Flotation Tailing Dump in Bor (Field 1 and Field 2), in 2011/12, Fund of Technical Documentation, Geology Department, MMI Bor; 2011, p. 44.

[3] Maksimović M.: Project of Explorations and Testing the Flotation Tailing Dumpsand Open Pit Waste Dumps Bor, in the Area of Inactive Ecological Exploitation Field Related to the Activities of Remediation by the World Bank, Fund of Technical Documentation, Geology Department, MMI Bor; 2011, p. 55.

[4] Maksimović M.: Project of Geological-Ecological Exploration and Testing Within the Endangered Ecological Zone - Tailing Dumps in Bor (Dam 2), Fund of Technical Docu-mentation, Geology Department, MMI Bor; 2012, p. 20.

[5] Maksimović M.: Elaborate on Realized Geological Explorations and Testing the Flotation Tailing Dumps and Open Pit Waste Dumps Bor, in the Area of Inactive Ecological Exploitation Field Related to the Activities of Remediation by the World Bank, in the period 2011/12, Fund of Technical Documentation, Geology Department, MMI Bor; 2012, p. 83.

[6] Report of the Consulting Company Witteveen + Bos, according to the Project of the World Bank "Bor Regional Development", the component $\mathrm{A}$ - remediation of the flotation tailing dumps and relocation the Krivelj collector, Fund of Technical Documentation, Geology Department, MMI Bor; 2012, p. 50. 


INSTITUT ZA RUDARSTVO I METALURGIJU BOR $\quad$ ISSN: 2334-8836

UDK: 622

Miroslava Maksimović, Milenko Jovanović, Goran Pačkovski", Vladan Marinković

\section{PRELIMINARNI GEOLOŠKI ISTRAŽNI RADOVI U CILJU UPRAVLJANJA ŽIVOTNOM SREDINOM NA PROSTORU NEAKTIVNOG EKOLOŠKOG EKSPLOATACIONOG POLJA ${ }^{* *}$}

\section{Izvod}

Bor je inače tipični rudarski grad, nastao uz rudnik. Nastavak privređivanja u dominantnoj oblasti ekstraktivne industrije, vezanoj za eksploataciju i preradu rude bakra, zatim za metalurgiju $i$ komplementarne industrijske delatnosti, od izuzetnog je značaja za grad i opštinu. Severni deo timočkog magmatskog kompleksa i borske metalogenetske zone, odnosno borski rudni reon, obuhvata prostor u kome su najznačajnija rudna polja Bor, Veliki Krivelj, Cerovo, Majdanpek, Blagojev Kamen i dr.

Najveće tehnogene tvorevine izdvojene su u neposrednoj okolini Borskog i Kriveljskog rudnika, $i$ predstavljene su tvorevinama koje su nastale eksploatacijom rudnih ležišta bakra (raskrivka) $i$ pripremom mineralnih sirovina (flotacijska jalovišta), u neposrednoj okolini Bora.

Projektovani istražni radovi na prostoru neaktivnog ekološkog eksploatacionog polja imali su za cilj da se pripreme uslovi za upravljanje životnom sredinom, remedijacijom jalovišta i deponija za odlaganje rudničkog otpada u Borskoj rudarskoj oblasti, kao i sanacija ekoloških problema u rudnom reonu Bor. Istražni radovi obuhvatili su istraživanje terena: za odlaganje jalovine Veliki Krivelj, prostora Starog Borskog jalovišta, (Istok) Saraka deponija jalovine, jugo-istočne deponije jalovine i RTH.

Ključne reči: tehnogene tvorevine, neaktivno ekološko eksploataciono polje, eksploatacija rude, jalovišta, deponije za odlaganje rudničkog otpada

\section{UVOD}

Morfologija terena na području šire okoline istražnog prostora, bitno utiče na način i uslove istraživanja i eksploatacije, te uslove transporta rude i koncentrata, i načina odlaganja tehnogenih tvorevina. Slično je i sa hidrološkim uslovima, a pre svega vodenim tokovima.

$\mathrm{Na}$ reljef terena, u širem području Bora, znatan uticaj imala je intenzivna vulkanska aktivnost (krajem mezozoika i tokom kenozoika), praćena snažnim tektonskim pokretima. Tektonski pokreti, koji se ogledaju u razlamanju, gravitacionim i reversnim pokretima blokova, kao i u nabiranju terena, uticali su na primarno modeliranje geomorfoloških oblika, koji su dalje modifikovani uticajem egzogenih faktora.

Međutim, na formiranje sadašnjeg izgleda reljefa uticala je i privredna aktivnost u mineralno-sirovinskom privrednom kompleksu (slike 1, 2, 3). Procesi eksploatacije, pripreme, i prerade ruda u Boru i okolini, uslovili su promene reljefa i nastajanje pojedinih inverznih morfoloških oblika, kao

\footnotetext{
* Institut za rudarstvo i metalurgiju Bor

** Ovaj rad je rezultat Projekta br TR: 37001 „Uticaj rudarskog otpada iz RTB Bor na zagađenje vodotokova, sa predlogom mera i postupaka za smanjenje štetnog dejstva na životnu sredinu“, finansiranog od strane Ministarstva prosvete, nauke i tehnološkog razvoja Republike Srbije.
} 
što su površinski kopovi i deponije (stenske otkrivke, rudničke jalovine, flotacijske jalovine, topioničke šljake, piritnih ogoretina).

Eksploatacija borskog ležišta, od početka prošlog veka, zahvatila je 26 rudnih tela, dobrim delom $\mathrm{u}$ isto vreme površinskom $\mathrm{i}$ podzemnom eksploatacijom, (slika 1). Pri tome je dobijeno ukupno 146.270.000 t rude bakra iz koje je estrakovano 2.437 .000 tona metala bakra, $139.140 \mathrm{~kg}$ zlata i $415.000 \mathrm{~kg}$ srebra. Takođe je otkopano i 436.200.000 tona jalove mase (otkrivke i pratećih stena).

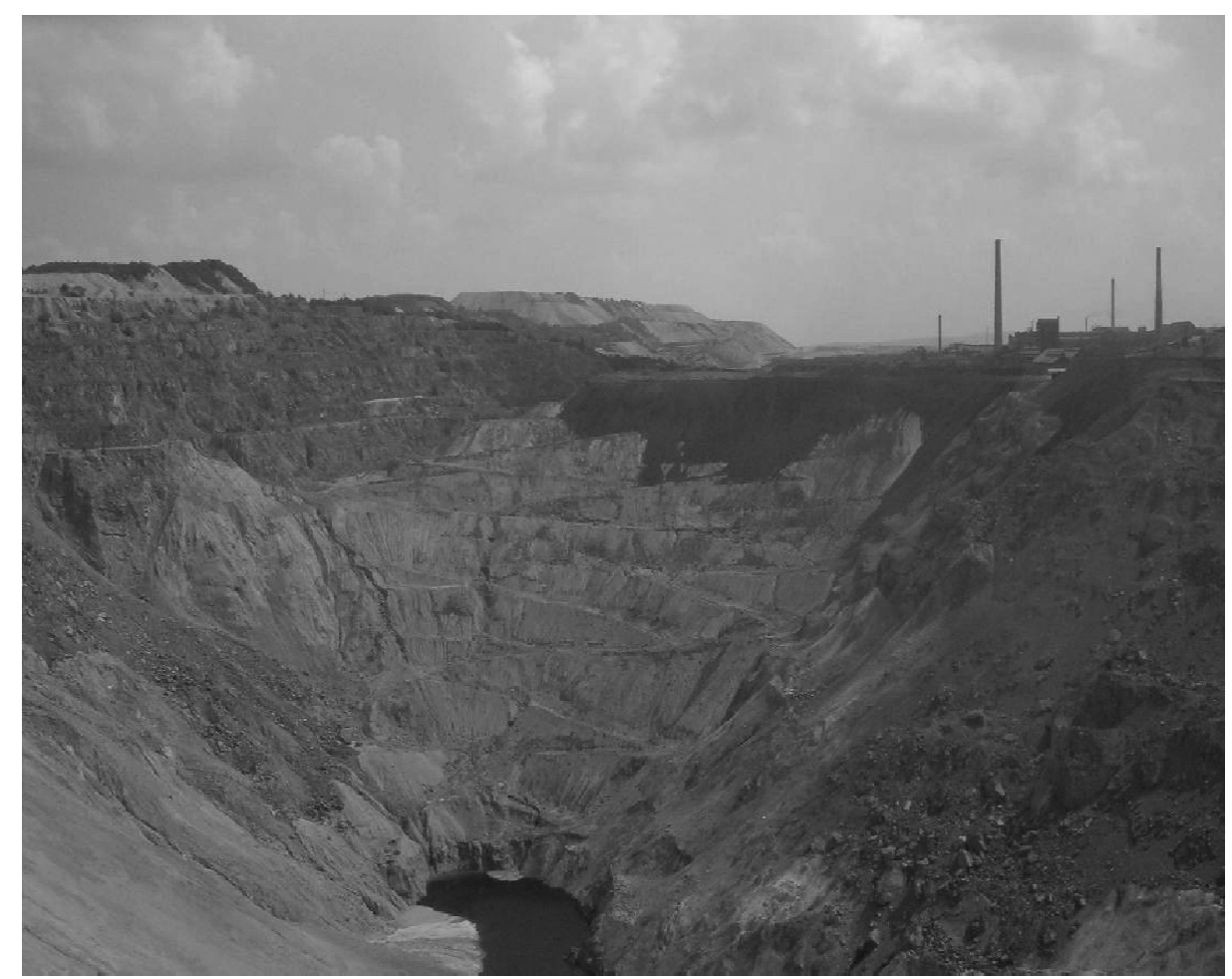

SI. 1. Stari borski površinski kop (avgust 2005)

Eksploatacija ležišta bakra, starim površinskim kopom u Boru (slika 1.10), a kasnije i podzemnom eksploatacijom, kao i obogaćivanje rude $\mathrm{i}$ dobijanje koncentrata $\mathrm{u}$ borskoj flotaciji, uslovile su izmene paleoreljefa, u smislu degradacije prirodnog reljefa, uz stvaranje uzvišenja od nagomilanih materijala flotacijske jalovine. Metalurška prerada koncentrata uslovila je stvaranje deponija šljake. Najveća količina šljake odložena je na lokalitetu između povr- šinskog kopa rudnog tela „H“ i bivšeg prališta radionice starog površinskog kopa, pa je ova lokacija poznata kao „Depo šljake - 1. (Maksimović M., Nikolić K., 2005.).

Prvi radovi na raskrivanju na površinskom kopu Veliki Krivelj počeli su 1979. godine. Otkopavanje rude bakra počelo je 1982. godine i ukupno je otkopano i prerađeno oko 198 miliona tona rude sa oko 689.000 tona metala bakra i oko 179 miliona tona jalovine. (slika 2) 


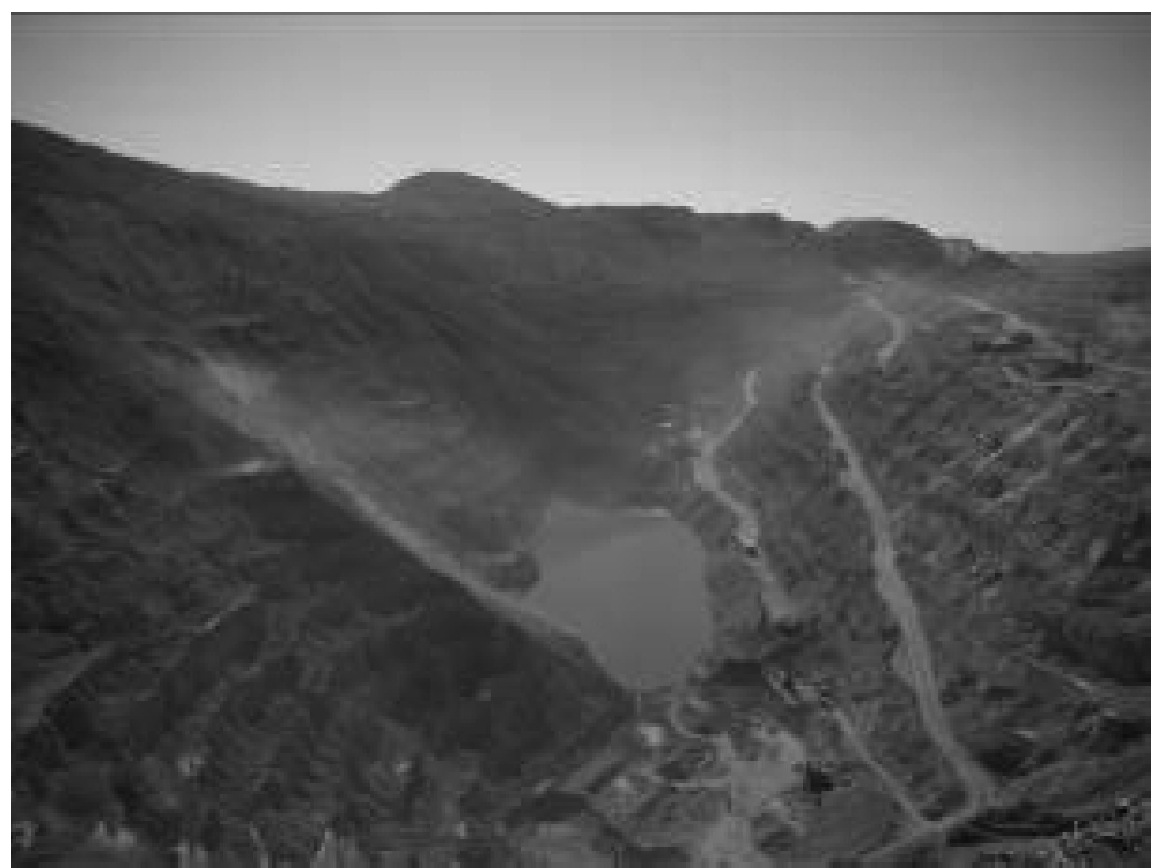

SI. 2. Izgled PK Veliki Krivelj (2012)

Prerada rude bakra površinskog kopa Veliki Krivelj obavlja se u pogonu Flotacija Veliki Krivelj. Projektovani kapacitet Flotacije Veliki Krivelj je 8.000.000 tona suve rude godišnje, ili iskazano preko časovnog kapaciteta $342,5 \mathrm{t} / \mathrm{h}$ suve rude po sekciji.

Jalovište Flotacije Veliki Krivelj je, zbog različitog vremena izgradnje i kori- šćenja podeljeno u dva dela - polja. Polje 1 zauzima prostor između brana $1 \mathrm{i} 2$, a polje 2 prostor između brana 2 i 3 . Korišćenje polja 1 je započelo u decembru 1982. g., a privremeno prekinuto septembra 1990. g. Polje 2 se koristi od septembra 1990. g. i danas je aktivno.

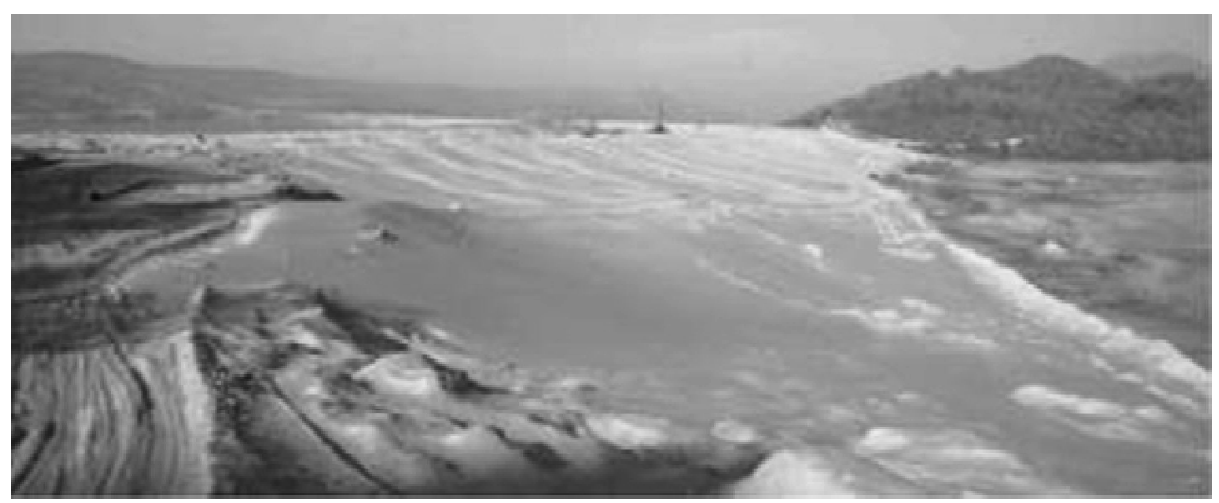

SI. 3. Brana 2 kriveljskog flotacijskog jalovišta (2011) 


\section{PRELIMINARNI ISTRAŽNI RADOVI}

Preliminarni istražni radovi usmereni su na ispitivanje terena za istraživanje, sanaciju, remedijaciju i rekultivaciju: Starog Borskog flotacijskog jalovišta: deponije jalovine odlagališta Veliki Krivelj, stabilnost Brane, 2 i 3 na polju 2, Saraka deponije jalovine, jugo-istočne deponije jalovine i RTH. (slika 4).

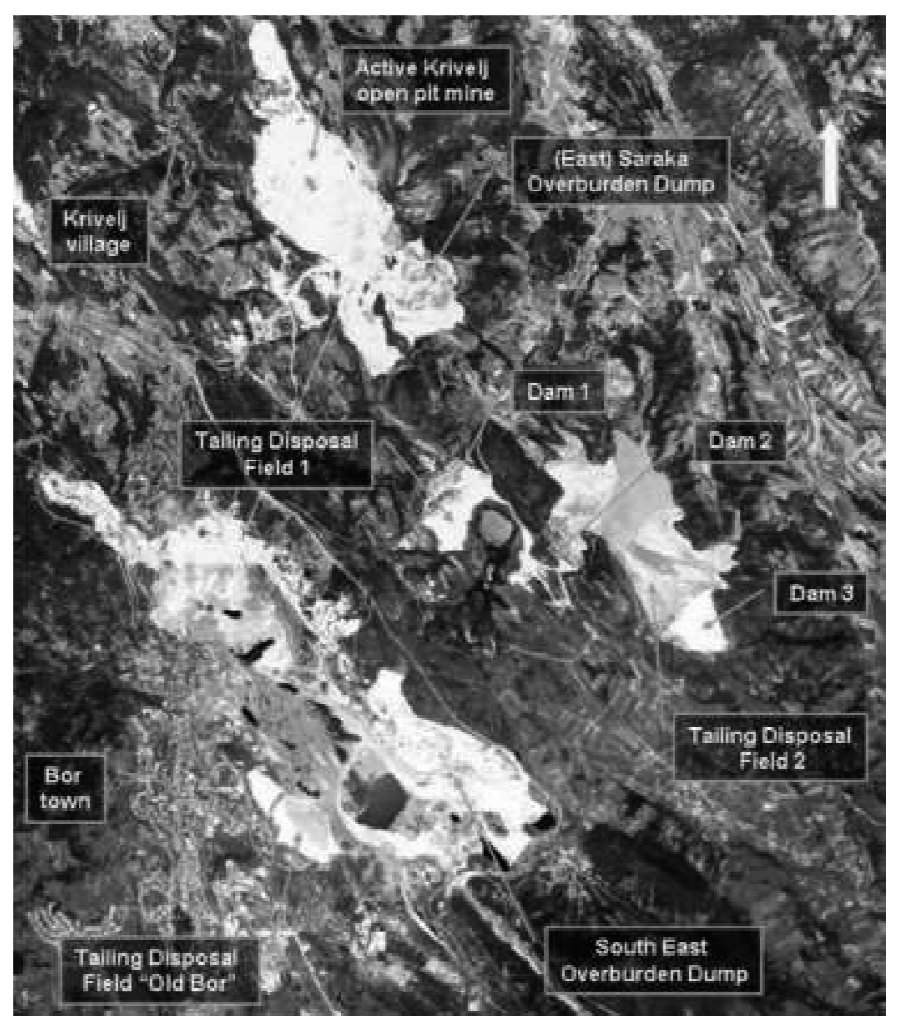

Sl. 4. Situacioni plan deponija i odlagališta jalovine (2011)

\section{CILJ ISTRAŽIVANJA}

Osnovni ciljevi istraživanja su:

1. Mere suzbijanja isticanja otpadnih voda sa deponija i remedijacije (uglavnom materijal rudničke jalovine).

2. Stabilnost brana,

3. Upravljanje vodom (atmosferske vode, vode iz pretakanja, curenje vode, nekontrolisanje curenje vode i izlivanje mulja),

4. Zatvaranje i remedijacija deponija jalovine u Boru, i delimično ponovno obnavljanje (sađenje) vegetacije i,

5. Monitoring i održavanje posle izgradnje. 
Posebna pažnja posvećena je rehabilitaciji/preusmeravanju baj-pasa reke (kolektor) koji je sada ispod jalovišta Veliki Krivelj.

Ciljevi ovog posebnog zadatka su:

1. ispitivanje lokacije,

2. projektni radovi,

3. razvoj uticaja na životnu sredinu,

4. izrada plana upravljanja životnom sredinom,

5. priprema plana monitoringa za rehabilitaciju i remedijacija.

\section{Specifični ciljevi}

1. Sprovođenje ekološkog ispitivanja terena i geološka i hidrogeološka istraživanja radi dobijanja podataka za buduću remedijaciju/rekultivaciju zemljišta;

2. Elaborat ulaza za punu procenu uticaja na životnu sredinu, projekti upravljanja zaštitom životne sredine i projekti sanacije lokacija.

Preliminarni geološki radovi obuhvataju: istražno bušenje radi uzimanja uzoraka za utvrđivanja hemijskog sastava, testove luženja, rudničke i flotacijske jalovine, utvrđivanje geološke građe paleoreljefa, ugradnju piezometara radi praćenja kvaliteta i nivoa voda, uzimanje uzoraka za testove generacije kiseline i neutralizacije inženjersko-geološka ispitivanja radi utvrđivanja stabilnosti brana (Maksimović M., 2011., 2012.).

Pored geoloških istraživanja na terenu, dalja istraživanja obuhvataju neke specifične aktivnosti koje su relevantne za sanaciju i rekultivaciju predmetnih prostora. Ove aktivnosti su: uzorkovanje površinskog zemljišta (potencijalnih) površina deponija rudničke i flotacijske jalovine radi izrade testova generalizacije kiselina i neutralizacije; testova biološke rekultivacije uključujući i testove malog obima na terenu sa biljkama; testove biološke rekultivacije za procenu podobnosti za uslove rasta biljaka.

Uopšteno, istraživanje terena počela su sa detaljnijim testovima prodiranja osnove odlagališta rudničke i flotacijske jalovine radi procene sastava tla. Dalji istraživanja nastavljena su istražnim bušenjem. Finalni položaj i dubina piezometara su odabrani na osnovu testova prodiranja i jezgrenog bušenja i stratigrafije zemljišta koja je utvrđena tokom bušenja.

Mreža testova statičkog sondiranja, do 5 metara dubine, izvedena je pre mreže testiranja smicanja i jezgrenog bušenja.

$\mathrm{U}$ cilju provere efikasnosti predložene stabilnosti i mera za smanjenje curenja, sveobuhvatan plan monitoringa koji je urađen i sproveden, sastoji se od instrumentalnog praćenja i vizuelne inspekcije.

Rezultati izvedenih istraživanja $\mathrm{i}$ ispitivanja

Flotacijska jalovišta i same brane na jalovištima, su godinama građene od materijala ciklonske jalovine, koji se sastoji od finozrnastog (alevritskog) do krupno-zrnastog peska (rastresitog materjala).

Stabilnost brana je osigurana sve dok se nivo podzemnih voda unutar tela brana može održavati ispod bezbednog maksimalnog nivoa, posebno uzimajući u obzir očekivane seizmičke uslove. Sadašnji napori da se kontroliše nivo podzemnih voda su nedovoljni što dokazuje visok iznos (kontaminiranog) curenja koja se sada pojavljuju kroz brane. (Maksimović M., 2011, 2012.)

Za uspešnu realizaciju Projekta remedijacije neophodno je da trenutni priliv procednih voda bude zaustavljen.

Pre preduzimanja mera, preporučuje se da se prvo sprovede brza procena rizika radi utvrđivanja eventualnih uticaja mogućeg propadanja brana i da se proveri efikasnost $\mathrm{i}$ obim predloženih mera sanacije aktivnih jalovišta i remedijacije i rekultivacije neaktivnih deponija.

$\mathrm{Na}$ osnovu izvedenih istraživanja i ispitivanja utvrđeno je da treba preduzeti sledeće mere:

- Plan vegetacije treba da bude donešen za kosine brana u cilju sprečavanja buduće površinske erozije ispune brane; 
- Redizajn drenažnog sistema za sprečavanje curenja i poboljšanje stabilnosti kroz sistematsko i efikasno spuštanje nivoa podzemnih voda unutar brana i u njihovoj neposrednoj blizini.

\section{ZAKLJUČAK}

Istražni prostor koji se nalazi na području neaktivnog ekološkog eksploatacionog polja je prostor, na kome je potvrđeno prisustvo, opasnih i štetnih materija uzrokovano ljudskom aktivnošću, u koncentracijama koje mogu izazvati značajan rizik po ljudsko zdravlje i životnu sredinu.

Područje neaktivnog ekološkog eksploatacionog polja istraživan je istražnim bušotinama sa površine terena. Izvedenim geološkim istraživanjima dobijeni su preliminarni podaci o geološkoj gradi, fizičko-mehaničkim i hidrogeološkim osobinama, područja neaktivnog ekološkog eksploatacionog polja.

$\mathrm{Na}$ osnovu rezultata izvršenih istraživanja $\mathrm{i}$ ispitivanja predložene su dalje mere radi sanacije predmetnog prostora, i smanjenja zagađenja. Daljim istraživanjima dobiće se rezultati za preduzimanja mera za zaustavljanje zagađenja i dalje degradacije životne sredine do nivoa koji je bezbedan za buduće korišćenje lokacije uključujući uređenje prostora, revitalizaciju i rekultivaciju.

\section{LITERATURA}

[1] Maksimović M., Nikolić K. i dr.: Elaborat o rezervama ležišta bakra Bor (rudna tela "Brezanik", "Tilva Roš" i "P2A"), stanje 31.12.2004.-tekstualni deo, Fond stručne dokumentacije,
Odeljenje za geologiju IRM, Bor; 2005, s. 144.

[2] Maksimović M.: Projekat detaljnih geoloških istraživanja bakra i drugih korisnih komponenti na prostoru Starog flotacijskog jalovišta u Boru (Polje 1 i Polje 2), u 2011/12. godini, Fond stručne dokumentacije Odeljenje za geologiju IRM, Bor; 2011, s. 44.

[3] Maksimović M.: Projekat istraživanja i ispitivanja flotacijskih i kopovskih jalovišta Bor, na području neaktivnog ekološkog eksploatacionog polja, vezano za aktivnosti na remedijaciji od strane Svetske banke, Fond stručne dokumentacije Odeljenje za geologiju IRM, Bor; 2011, s. 55.

[4] Maksimović M.: Projekat geološkoekološkog istraživanja i ispitivanja u okviru ugrožene ekološke zone Jalovišta u Boru (Brana 2), Fond stručne dokumentacije Odeljenje za geologiju IRM, Bor; 2012, s. 20.

[5] Maksimović M.: Elaborat o izvršenim geološkim istraživanjima $\mathrm{i}$ ispitivanjima flotacijskih i kopovskih jalovišta Bor, na području neaktivnog ekološkog eksploatacionog polja, vezano za aktivnosti na remedijaciji od strane Svetske banke, u periodu 2011/12. Godine, Fond stručne dokumentacije Odeljenje za geologiju IRM, Bor; 2012, s. 83.

[6] Izveštaj konsultantske kuće Witteveen + Bos, po Projektu Svetske banke "Bor regional development", komponenta A-remedijacija flotacijskih jalovišta i izmeštanje kriveljskog kolektora., Fond stručne dokumentacije Odeljenje za geologiju IRM, Bor; 2012, s. 50. 